\title{
Awarded with Economic Growth, from Weak to Strong Patent Legislation: Legal Study with Regard to
} China

\author{
Shaghayegh Haji Bagher Naeeni \\ Symbiosis Law School, Pune, India \\ Shaghayegh@live.in
}

\begin{abstract}
This paper provides a critical legal study on evaluation of patent system in China from the year1980, which is known as the beginning of Chinese modern intellectual property law including patent law till 2016 that China achieved third place in Patent Cooperation Treaty (PCT) internationally for the highest patent applications according to World Intellectual Property Organization (WIPO). Moreover, researcher will go through few important push factors for Chinese patent legislator who developed stronger Patent law to attract more national and international inventors for investing in Chinese market without hesitation of their patent rights being infringed due to weak legislation. In other words, how China realized that being in the era of globalization for improving economic growth, it should consider at least minimum international standards in its own patent legislation. Hence, the method used in this paper will be purely a doctrine method, because the researcher will be conducting the critical legal study on mentioned aspects, which involves collecting of data from primary and secondary sources. The process involved in this research is a collative process. However, still there is room for improvement in current Chinese patent system, which will be discussed in this paper. All in all, the researcher concluded that concept of globalization is undeniable in national as well as international market in order to have a reasonable economic growth for the same reason china had considered having stronger patent legislation in order to save its position in the market and also to increase its own rate of economic growth. On the other hand, the paper concludes by putting forward suggestions for modifying Chinese patent system.
\end{abstract}

Keywords: China, patent legislation, patent right, globalization, Economic growth

\section{Introduction}

Formerly, china was not interested to establish strong Intellectual Property (IP) law, including patent framework and operational system. Since the concept and importance of it was not known and experienced by people and policy makers. Consequently there was not a concern for need of the change for the said law. Correspondingly, to begin with adopting strong IP legislation they had to discontinue any commercial activity that leads to infringement of any kind of IP rights of originator. In other words, their consent would be necessary in order to use their original creation, and considering china being a market that had economic growth for duplicated merchandises of the well known brands with cheaper price and sometimes poorer quality, it would not be such a welcoming idea to set end to all their activities by adopting strong IP including patent legislation. With the new situation in hand, need for accurate strategy to prevent any kind of economic crisis was essential. However, there were other important aspects as well, such as global warming or new disease, which needed research and new invention to put end to such issues, and it wouldn't be possible if there weren't any kind of rights given to the inventor or creator to develop a solution. Plus, other reason like considering need for deliberating concept of globalization in legislation's strategy in order to have healthier international trade and market. Besides, communication through different kind of medium such as Internet, it transformed the market to be more accessible for people in distance and also undeniable fact that countries need each other in different technology and knowledge in order to fill their gap and survive different crisis. Also, it can result to having a better economy as well. China also with considering all possible aspects begun to welcome stronger IP system including patent legislation even if it was really challengeable for her, but yet Chinese policymakers understood with accurate transformation toward better IP (patent) legislation they could not only develop solution to their needs but also to achieve remarkable economic growth. Because, with their tendency of reverse engineering they already educated themselves from other countries technology and knowledge, there were great time for them to establish their part in the market and protect their creation as well as put the stop to fear of the other countries to invest and bring their knowledge and expertise to china without worrying of their right to be infringed. In other worlds, it was time to be frontrunner in patent system. China started to join intentional conventions and treaties in order to lay down accepted universal patent standard and amended her patent Act in order to bring harmony in her domestic related patent law. 


\section{Literature Review}

- Beginning with this research and going back through patent history and where it is originated $\mathbf{V} \mathbf{k}$ Ahuja, Law Relating to Intellectual Property Rights and Thomson Reuters, The history of patent (2017) points out important aspects about history of patent around world.

- Moreover, with regard to transformation made by Chinese government and legislator on Patent system, WIPO Magazine, China's IP Journey and DONGMIN CHEN, SHILIN ZHENG, and LEI GUO, Peking University, The Impact of Science and Technology Policies on Rapid Economic Development in China stated the agendas of china with regard to this matters and how all these discussions started and effect of them on Chinese economic growth.

- Cornell University, INSEAD, and the World Intellectual Property Organization (WIPO), The Global Innovation Index 2017: Innovation Feeding the World (tenth edition)and World Intellectual Property Report (WIPO), Breakthrough innovation and economic growth (Economics and statistics series) 2015and Federal Ministry of Education and Research, China Strategy 2015-2020, deals with global investment growth which gives interesting information with regard to place of China in investment growth in 2017 and how China is rapidly growing. Although, she is facing some issues in this path and process. On the other hand, movements for better IP legislating in order to have a better economic Growth.

- Huaiwen He \& Ping Zhang, Impact of the Intellectual Property System on Economic Growth Fact, Finding Surveys and Analysis in the Asian Region (Country Report - China) call attention to evolution of patent system. Which, include patent amendments and modification in order to reach to perfection.

- World intellectual property organization (WIPO), who filed the most PCT patent applications in 2016? And World intellectual property organization (WIPO), International Patent Filings Set New Record in 2011 last but not the least, World intellectual property organization (WIPO), International Patent Filings Set New Record in 2011stated how China keeping up with international patent standards and becoming member to different treaties and conventions and therefore China is in road to becoming frontrunner in patent.

- V k Ahuja, Law Relating to Intellectual Property Rights also in short laid down different patent convention and treaties along with their agendas and their enforcement.

- World intellectual property organization (WIPO), Advisory Committee on Enforcement (Eleventh Session) and Shenging Yang, Patent Enforcement in China, these papers through light on IP protection and enforcement in China.

- SIPO Annual Report 2016 (patent application and exanimation), it is a very precise report along with tables for demonstration of number of applications with respect to foreign and domestic inventor along with China patent status in 2016.

- World intellectual property organization (WIPO), China: IP Laws and Treaties, provide list of all Chinese IP related Acts, conventions and treaties which is really helpful to be updated about patent evaluation in China.

\section{Methodology}

The research methodology of the paper will be purely doctrinal method, because the researcher will be conducting the critical legal study on awarded with economic growth, from weak to strong patent legislation: Legal study in regard to China. This research will follow a collative process. A primary source it includes study of case material collected from various books. In secondary sources it includes websites, Internet articles.

\section{Results}

Patent Originated: It should be taken into consideration that throughout ancient area, there was some kind of award for creator or inventor. Which, later on all came under one umbrella known as intellectual property law and it comes in different forms, however scope of this paper will be only limited to patent and its effect on economic growth."Patent" derived from the Latin word "literate patents" which means open letter. And the reason for choosing this name was because in medieval time, emperors used to give protection confer rights 
and privileges through the letter which used to be provided to the inventor with royal seal which was proof of those right (Ahuja, 2012). Although around the world there were different ways to pay their respect to inventor. Moreover, it is accepted that the first informal patent system was developed in renaissance Italy. Additionally, 'Émigré vention' was glass- blowers who introduced patent system to rest of Europe with the purpose of protecting their skill versus the other local worker. First official patent record belongs to John of uthynom for 20 years monopoly for a process with regard to glass making in 1499. With regard to North America, they followed the familiar system but they limited monopolies and in 1788 they did ratify Article1, Section 8:

'The Congress shall have power ... to promote the progress of science and useful arts by securing for limited times to authors and inventors the exclusive right to their respective writing and discoveries'.

Considering the above examples of patent system evolution around the world (Thomson Reuters, 2017). There were many reasons to draft and codified patent legislation and perhaps one of the reasons could be how these inventions could help countries to develop and have direct effect on economic growth. In other word, when a country gives proper protections and right to inventor, eventually there will be more encouragement and motivation to develop new idea, which can lead to improvement in field of the invention and related industry of it. Certainly, that will result to having demand in market because mostly main purpose of invention is to fulfill the specific need of people that can be in form of goods or services. Therefore, there will be a place in market for that product nationally or sometimes internationally as well. In process of idea turning to product for specific need and been sell in national or international markets; there will be different procedures involved to reach to desirable outcome which can be result to economic growth because of money exchange engage in this process. China is a great example of developing her intellectual property law including patent for becoming stronger, which resulted to mesmerizing economic growth.

Weak to strong patent legislation: With considering the above-mentioned aspects there was needed for Chinese legislators to outline stronger Intellectual Property (IP) Law including patent. Although, it wasn't a one-day progress, there was a requirement to understand demands of the country with regard to this matter. On the other hand, being one of the main players in the international market the concept of globalization was undeniable. Therefore, this transformation needed smart movement to adopt international standard in domestic law. It wasn't an easy process and still there is a room for improvement for stronger patent system. However, this evaluation was and is fascinating, which will be discussed in this paper.

Chinese domestic patent system: China started the movement from her domestic law by laying down Patent Act and amending it according to issues arising to create suitable patent legislation. Modern patent legislation in China was asserted on 12 March1984, which came to the force on 1 April 1985. However, in order to make the Act more practical and in harmony with international patent standards, there were been few amendments to the Act.

A. The first amendment was On 1992, following are important modification made by it:

- There was an alternation with respect to the term of patent protection. For instance with regard to invention patents term of protection extended from 15 to 20 years and also duration of protection extended for industrial design patent from 5 to 10 years.

- Furthermore, scope of patent extended and included Pharmaceuticals, food and drinks and chemical product. Also approved some other quantity to support patent protection.

B. The next amendment was in Sept 2000,

- It removed the provisions with regard to preventing state owner enterprises from trading their patent in technology market,

- They initiated new provisions aimed to make it more fulfilling for employee to innovates,

- On the other hand, some of the provisions were not in harmony with Trade Related aspect on Intellectual Property rights (TRIPS) agreement, for instance changing and increasing term of protection for patent to offering for sale patented products.

C. Third Chinese patent amendment took place on 2008. The main changes into the Act were:

- Improving the approach of patentability by changing the conditions from relative to absolute novelty that is one of the elements (novelty, inventiveness and industrial applicability) of patentability in china. 
- Moreover, providing regulations on the protection of genetic resources and also improving industrial design systems;

- And improving confidentiality examination procedure for application to a foreign country.

- Canceling the designation of foreign related patent agencies and cumulative the responsibility of the State Intellectual Property Office (SIPO) for the circulation of patent information also awarding right holders of industrial design with the right to offer to sell,

- Introducing pre-litigation preservation measures,

- And including the cost to the right holder incurred for stopping the infringing act to the calculation of damage compensation;

- Codifying the prior art defense;

- Allowing parallel imports;

- Providing exceptions for drug and medical apparatus experimentation;

- And improving the compulsory license system.

D. The fourth amendment as State Intellectual Property Office (SIPO) mentions it supposed to come to force on 1 April 2017.

- In this amendment a provision was added with intention of protecting business model in case, which there is a technical feature involved apart from the description of the business rule and method.

It opens the door for protecting a business method under the patent law.

- Moreover, several amendments are introduced concerning patent applications for an invention relating to computer programs with clarifying difference of computer program from media plus a program as a component part also clarify that a claimed directed to a device may include a program as a component part. Furthermore, the term "function module" is replaced by "program module" for a better reflect. The technical nature and differentiate from the term "functional definition"

It is shown that SIPO opens to protecting computer-implemented inventions under the patent law.

- Provisions with respect to post-filing data got amendment, under new provisions. It is specified that the examiner shall have to examine the experimental data submitted after the filling date, although the technical effect indicated by the experimental data shall be obtained based on disclosure contained in the preliminary description and claims, from the viewpoint of a person skilled in the Act.

It seems that SIPO has become more tolerant to the application with respect to the invalidation procedure,

- The new amendment is more relaxed on patent document, mentioned that it is acceptable to incorporate one or more technical features declaimed in other claim into a claim so as to limit the protection scope and that is allowed to correct obvious error in the claim. With regard to new invalidation grounds and new evidence, amendment laid down new ground concerning the claim that have been emended by incorporating technical features recited in other claim or by correcting obvious errors, shall be limited to responding to such contents.

- Moreover, the provisions with regard to additional evidence with specified time limit in response to amended claim by way of combination may present by petitions have been removed from the act.

It leads to a more advantageous position in a patent invalidation procedure for patentees.

- In this amendment, the opportunity given to the public to have broader scope with respect to contents accessibility. In other words, anyone may consult and photocopy notifications, search reports and decision issued during the substantive examination procedure for a patent application under examination as well as the priority document for a patent.

- Last but not the least, the examination guideline is amended and in harmony with the new civil procedure law, identifying that the patent office shall suspend relevant procedures for the period indicated by a civil order or notification on assistance in the execution issued by a people court in relation to property preservation.

All in all this amendment notes that SIPO be more friendly to applicants and provide better services for the public.

Above-mentioned points were some important modifications made by legislators although fourth amendment is not yet actively enforced. 
International Chinese patent system scenario: In case of statute like IP law, which is more used for collaboration of countries with regard to trade and transferring knowledge and technology, it is necessary to craft or amend law according to accepted international regulations by adopting modifications in current domestic law to prevent any future conflict in legal system between parties from different countries. Perhaps, the reason is in our epoch, the concept of globalization is undeniable. Globalization is nothing but the process of collaboration and integration amongst the governments, companies and people of different countries, which is motivated by international trade and investment and assisted by information technology. The said procedure has consequences on the environment, culture, political systems and economic growth and wealth. It is apparent that considering the purpose of IP law, there are common aims between globalization and IP law such as collaboration among countries for trade and investment with exchange of technology and knowledge which can be also in form of goods or services. In other words, IP right including patent challenge people to create goods and services or develop solution to different problems which is novel and applicable and it can lead to increase trade for the invention's country or even the transfer of technology can help other countries to overcome its problem which is facing for long time but did not discover any solution for it. This case can be mostly seen in medical issues. As it is mentioned earlier, if there is no appropriate patent protection there will not be much companies attracted to invest because of having fear for possibility of their invention been infringed.

Therefore, china realized the said issue and joined different international organizations, agreements, conventions and treaties and perhaps it was a big step taken by China for accepting the power and importance of the need for globalization and be more welcoming towards international patent standards. Following are different international organizations, agreements, conventions and treaties that china became member of:

- China finally became $143^{\text {rd }}$ member of the World Trade Organization (WTO) on 11 December 2001 after 15 years of exhaustive negotiations.

- And for fulfilling the requirement of WTO joined Trade Related aspect on Intellectual Property rights commonly known as TRIPS agreement. According to TRIPS agreement minimum standard laid down in it should be followed and applied by member countries. Therefore, as it mentioned earlier in order to create harmonize between municipal patent laws with TRIPS agreement there were amendments made in Chinese patent system.

- Subsequent, china became member of World Intellectual Property Organization (WIPO) and it came

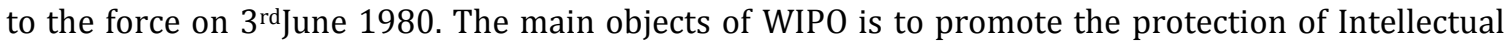
property (IP) around the world and also with the help of different treaties under its control, administer the member countries and prevent any kind of IP legal conflict between them. In other word, try to reduce and prevent any kind of barrier for having better interaction amongst members with regard to IP related issues. Considering these aims china in order to have an easier interaction with other member countries while IP matters are involved by joining WIPO make it much easier for domestic and foreign inventors to interact with each other.

- China joined Paris Convention for the protection of industrial design and it came to force on $19^{\text {th }}$ March 1985. Paris convention in addition to common rule which include patent offer the other basic rights known as the right to national treatment which is nothing but make it compulsory for member countries to grant same protection to national of other contracting states as it grant to its own national. Furthermore, right of priority was introduced which means in case of patent filling the priority given according to date of first application filed by the person in any member countries according to procedure and therefore his/her application will have a primacy over the other application with regard to same invention. With considering big argument with respect to doubt and risk of foreign inventor to invest their market on the base is of their unique innovation without worrying their patent rights been infringed, china by joining the said convention made it more easier for other nations to consider Chinese market without worrying and knowing that they will get same treatment as Chinese citizens also for Chinese and also if they register their application in other nations it will have a priority over other applications even by any mean someone else in china try for it.

- China joined Patent Cooperation Treaty (PCT) and became bound by it on $1^{\text {st }}$ Jan 1994. PCT is an exceptional agreement under the Paris Convention. PCT gives a chance to inventor by filling one set of form and related fees at once to national patent office of where they are from or resident or with 
international bureau of WIPO in Geneva, their application being considered in other member countries as well. However, the PCT regulate the formal requirements that any international application must comply according to them.

- China became a member of Strasbourg agreement concerning the international patent classification, which is commonly known as IPC agreement, and it came to force on $19^{\text {th }}$ Jan 1997. This agreement classified technology into 8 sections with around 67000-sub divisions. Every sub-division has a symbol consisting of Arabic numerical and letters of the Latin alphabet. Patent document has appropriate IPC symbol and national or regional industrial property offices that publish the patent document fix them. The important object is that the IPC is continuously revised and new edition is published every 5 years and the other significant of this agreement is that PCT uses the IPC classification therefore china also joined IPC to bring harmony in their international patent system and make it more user friendly in case of patent search and registration.

- China joined Budapest Treaty on international recognition of the deposit of microorganisms for the purpose of patent procedure and came into force on 19th Sep 1996. It deals with inventions that involve microorganism or the use of microorganism. Since there is not possible to in writing to disclosure of invention for patent procedure registration. Therefore, only it will be possible and effected by deposit of same microorganism with special institution. The Budapest Treaty make it sufficient for the purpose of patent procedure just by depositing sample with any 'international depositary authority' before the national patent office of all of contracting countries instead of depositing microorganisms sample in each country. China with joining the said treaty makes it possible for inventor who needed a patent protection through submitting microorganisms sample for completing their patent procedure and open the door for encouraging foreign and national inventors to create more and consider Chinese market with knowing that there can be possibility of protection according to international standards.

Chinese patent enforcement: There can always be a great law but it will not be meaningful if there is no proper enforcement for it. China domestic patent legislation went through different modification so that, it became harmonized with international standards and also to be more appropriate for Chinese inventors to follow it. Undoubtedly, Chinese patent legislation proceeds to have interesting transformation towards becoming strong. On the other hand, with regard to enforcement of patent there is still a room for improvement and make her hard work on Act count better. With regard to issues arising from infringement of patent under the Chinese patent system in addition resolving matter through arbitration or mediation. In cases that parties do not agree with these methods or do not get a desirable result after these procedures, then two ways are offered by Patent Act, one is judicial and the other is administrative. The standing committee of national people of congress in August 2014, made decision to establish its special IP tribunal in Beijing intermediate court, high court and supreme court of China. At same time court in different level that now they are around 410 tribunals by the end of 2013 there were 87 intermediate courts to adjudicate fist instance patent cases. And 7 basic courts for utility model patent and design patent cases. In other word, there were special court established in Shanghai and Guangzhou like Beijing. The three IP courts are equivalent to an Intermediate People's Court. They will act as an appellate court for civil or administrative judgments or decisions made by a lower court of first instance in the Beijing, Shanghai or Guangdong jurisdictions. In case that IP court acts as a first instance court, the IP tribunals of the High People's Court in said dominions will have appellate jurisdiction. Further appeals must be brought to the Supreme People's Court. The first 3 years, the IP court shall adjudicate cases from all area including patent within the province on municipality of the area.

Economic growth and evolution through patent law in china: China economic in recent decades was through interesting turn, which is more enthusiastically that of any country in the world. There are so many different aspects that leaded to this phenomenon. However, in this paper patent as an influence will be discussed. As it is mentioned earlier, combination of considerable production capacity and low production cost lead china to become the world-manufacturing powerhouse in year 1990. Nevertheless, China transitioned from a developing country to an emerging economy and also in some respects we can consider her as an industrial nation. Since, there was accepting by Chinese government that there should be more importance given to 'innovation', in other word, they declared target from moving from 'made in china" to 'invented and designed in china'. The upgrading of innovation system could be achieved by means of 
structural reforms and the forming of international partnerships and large financial investment in education, technology and innovation. And research policy set put by Chinese government which require plan such as the national medium and long term agenda for science and technology development (2006-2020) and the $12^{\text {th }}$ five years pan (2011-2015). With having objective of increasing research and development expenditure to a least of 2.5 percent of Gross Domestic Product (GDP) per year in the period up to 2020. Which means by the 2020, just 30 percent of the foreign technology will be needed in china; it means Chinese scientists should be reaching within top five in the world with regard to patents.

The aim of china from 'innovation initiative' is to establish itself as a province for the development and production of high technology products and to overcome technology gap and became technology frontrunner. China for achieving all these agendas needed strong IP legislation including patent. As it stated earlier that how Chinese patent system nationally and internationally went to transformation to be harmonized with accepted patent standard system by world so that it gives the opportunity and create encouragement for national and international inventor to arise with new creations and solutions to bring development in technology and science which leads to economic development. As a result of this movement from weak to strong patent legislation, one can witness from 1985 which first patent law came to force number of patent application changed dramatically by end of 1990. In 2014 the number of application raised to 928000 out of which 127000 were from foreign applicants and around one in four got registered and accepted. Also one from three of them was for foreign applicants, in other word 70548 out of 233288 . With regard to PCT, WIPO under its report placed china in $3^{\text {rd }}$ place for maximum patent application in 2016.

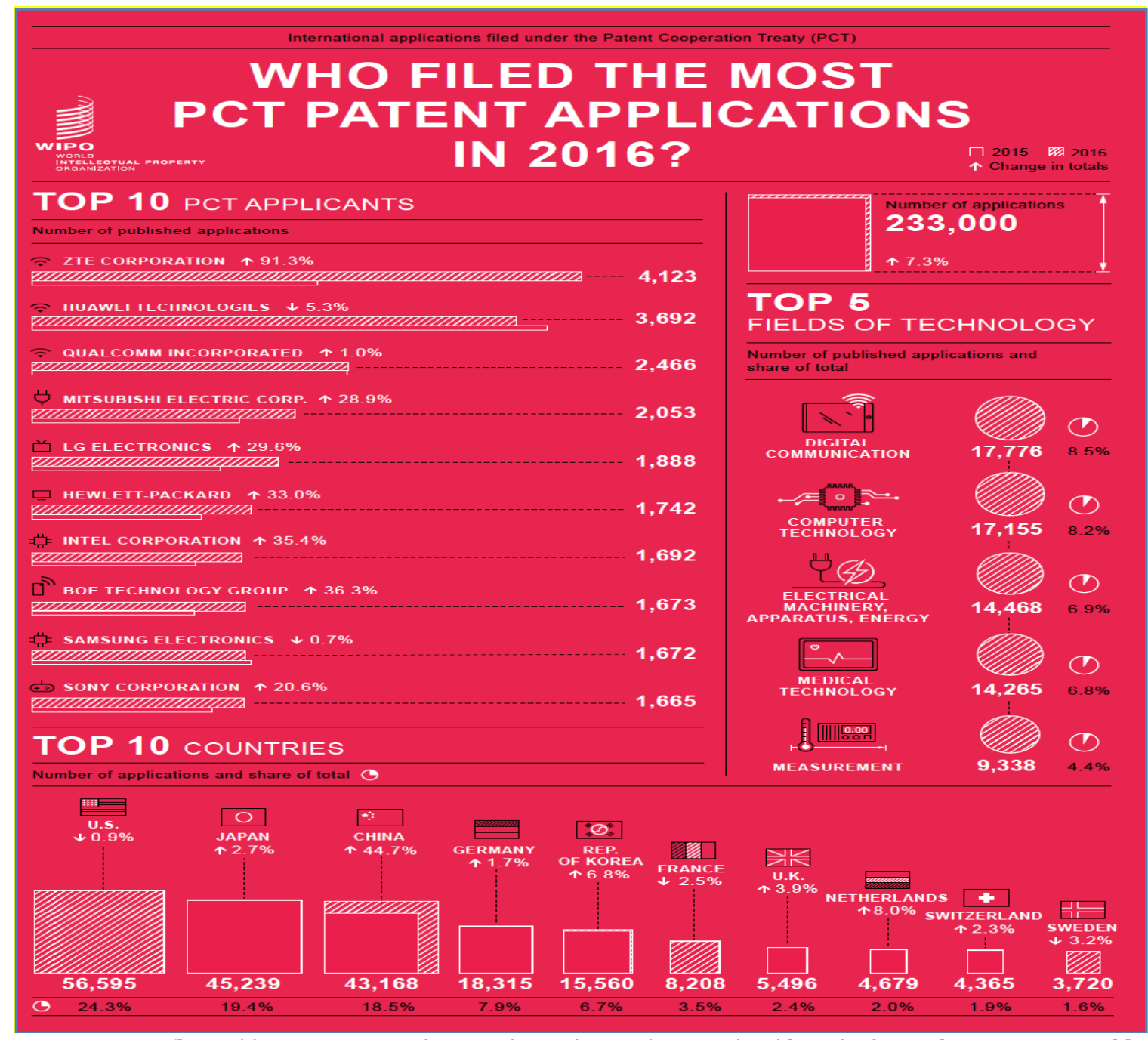

Source: WIPO(http://www.wipo.int/export/sites/www/ipstats/en/docs/infographic_pct_2016.pdf) 


\begin{tabular}{|c|c|c|}
\hline Table 1 & $\begin{array}{l}\text { Top 10 Domestic Enterprises Filing Invention Patent } \\
\text { Applications in 2016 }\end{array}$ \\
\hline No. & Name of Applicant & $\begin{array}{c}\text { Number of } \\
\text { Applications }\end{array}$ \\
\hline 1 & Huawei Technologies Co., Ltd. & 4906 \\
\hline 2 & China Petroleum \& Chemical Corporation & 4405 \\
\hline 3 & LeTV Holdings Co., Ltd. & 4197 \\
\hline 4 & ZTE Corporation & 3941 \\
\hline 5 & BOE Technology Group Co., Ltd. & 3778 \\
\hline 6 & Gree Electric Appliances Inc. of Zhuhai & 3569 \\
\hline 7 & Beijing Xiaomi Mobile Software Co., Ltd. & 3299 \\
\hline 8 & Nubia Technology & 3280 \\
\hline 9 & State Grid Corporation of China & 2912 \\
\hline 10 & OPPO Mobile Telecommunications Co., Ltd. & 2784 \\
\hline
\end{tabular}

Source: 2016 SIPO annual report(patent application and exanimation),

Comparing domestic enterprise that filing invention patent with PCT application in 2016, one can realize companies like Huawei Technology co. Ltd. Stand in second place in PCT by 3692 applications and first place in domestic enterprise table 4906 applications.ZTE Corporation hold first place in PCT by 4123 applications and $4^{\text {th }}$ place in domestic enterprise by 3941 applications. Moreover, BOE Technology Group Co., Ltd. Hold eight place in PCT by having 1673 applications and $6^{\text {th }}$ place in domestic enterprise by 3569.These are examples that how process of weak to strong patent legislations, encouraged inventor to create and apply for patent application not only national but internationally as well by given opportunity to companies which will automatically lead to having more shares in market with protecting their unique patent and attracting more consumers that will have effect on economic growth.

\begin{tabular}{|r|r|r|r|}
\hline Table 2 & Top 10 Foreign Enterprises Filing Invention Patent Applications in & 2016 \\
\hline No. & Country of Registration & Name of Applicant & $\begin{array}{c}\text { Number of } \\
\text { Applications }\end{array}$ \\
\hline 1 & Cayman Islands & Alibaba Group Holding Limited & 2974 \\
\hline 2 & Korea & Samsung Electronics Corporation & 2396 \\
\hline 3 & USA & Qualcomin Incorporated & 1936 \\
\hline 4 & Japan & Toyota Motor Corporation & 1831 \\
\hline 5 & Germany & Robert Bosch GmbH & 1524 \\
\hline 6 & Korea & Hyundai Motor Group Ltd. & 1347 \\
\hline 7 & USA & General Electric Company & 1295 \\
\hline 8 & Korea & LG Electronics Inc. & 1198 \\
\hline 9 & Japan & Mitsubishi Electric Corporation & 1164 \\
\hline 10 & USA & Ford Global Technologies, LLC & 1082 \\
\hline
\end{tabular}

Source: 2016 SIPO annual report(patent application and exanimation)

According to table 2 with respect to top 10 Foreign Enterprises filling invention patent application in 2016 with their best companies in countries such as Cyman Island, Korea, U.S.A, Germany. This all are movement 
made by the Chinese government and policy makers with regard to patent with considering the need for globalization and effect of having strong patent legislation in order to have economic growth.

\section{Conclusion}

All in all, China patent evaluation from weak to strong legislation is one of the most fascinating movements that history has been witnessing and it is undoubtful that soon china will be frontrunner with regard to patent in the world with having specific and clear agenda along with precise strategy for improvement of patent system in years to come. On the other hand, realization being made by Chinese people and policy makers that concept of globalization is undeniable and it is a need for countries to be associated in order to fulfill their gap and together survive economic crisis or to have a better economic growth. It is always known to legislator that law is far from technology and to make both meet each other at the same time it is a quite a hard work and sometimes it is impossible. With regard to IP law including patent it is really sensible. The reason is that it should cover all aspects of the inventions to promise best protection to the inventors. Therefore, there is need for amendment of patent Act time to time according to the need of the situation and harmonizing with international standards. Perhaps by just laying down provisions that are not specific and open to interpret according to situation will not be enough. Considering the complex nature of science and technology there is a need to understand them and with bearing in mind the description of it, propose appropriate provisions. It is acknowledged that china is in a path to become leader in patent internationally with her patent application arising in PCT and also seeing the foreign inventor registering in China and choosing Chinese market to invest for their invention.

\section{Suggestions}

- With regard to $4^{\text {th }}$ amendment that was supposed to come into force on $1^{\text {st }}$ April 2017, enough action must be taken with considering the important and necessary modifications sheltered by it and also it can smooth the patent procedure and make it more approachable.

- With respect to IP courts as it is mentioned only in first 3 years, it should judge the cases from all areas within the region or metropolis regions. There is a modification needed to deal with the after the said 3 years period and also set light on cases which are from other provinces.

- With considering high amount of filled applications and number of patent registration arising, it is clear that the issue in patent also will arise accordingly and for making the year of patent protection more valuable for inventor, it is necessary to establish more court to deals with these matter for insuring the more speedy trial and satisfaction for the patentee.

It is said that the road of achievement is always under construction. We have to keep working. I hope these suggestions would prove beneficial on the road of achievement of better patent protection for having better economic growth in china.

\section{References}

Ahuja, V. k. (2012). Law Relating to Intellectual Property Rights, reprint 2012-Websites

Cornell University, INSEAD, and the World Intellectual Property Organization (WIPO), The Global Innovation Index 2017: Innovation Feeding the World (tenth Edition), Available at: http://www.wipo.int/edocs/pubdocs/en/wipo_pub_gii_2017.pdf

DONGMIN CHEN, SHILIN ZHENG, and LEI GUO, Peking University, The Impact of Science and Technology Policies on Rapid Economic Development in China, Available at: http://www.wipo.int/edocs/pubdocs/en/wipo_pub_gii_2015-chapter6.pdf

Federal Ministry of Education and Research, China Strategy 2015-2020 Executive Summary (Strategic Framework for Cooperation with China in Research, Science and Education) Available at: https://www.bmbf.de/pub/China_Strategy_Kurzfassung_eng.pdf

For the Categories and Scoring Method to calculate Ginarte-Park Index of Patent, See, "Chapter 2: Index of Patent Rights" in the Economic Freedom of the World: 2002 Annual Report.

Huaiwen He \& Ping Zhang, Impact of the Intellectual Property System on Economic Growth Fact, Finding Surveys and Analysis in the Asian Region (Country Report - China) Available at: http://www.wipo.int/export/sites/www/aboutip/en/studies/pdf/wipo_unu_07_china.pdf 
National Bureau of Statistics of China. 2013a. China Statistical Yearbook 2013. Beijing: China Statistics Press. Available at: http://www.stats.gov.cn/tjsj/ndsj/2013/indexeh.htm

Shenging Yang, Patent Enforcement in China, Landslide Volume 4, Number 2, November/December 2011. Available https://www.americanbar.org/content/dam/aba/publications/landslide/landslide_november_2011 /yang_landslide_novedec_2011.authcheckdam.pdf

SIPO Annual Report (patent application and exanimation), 2016. Available at: http://english.sipo.gov.cn/laws/annualreports/2016/201707/P020170718522989362844.pdf

Thomson Reuters, The history of patent (2017), Available at:http://ipscience.thomsonreuters.com/support/patents/patinf/patentfaqs/history

WIPO Magazine, China's IP Journey, Available at:http://www.wipo.int/wipo_magazine/en/2010/06/article_0010.html (December2010)

World Intellectual Property Report (WIPO), Breakthrough innovation and Economic growth (Economics and statistics $\quad$ series) $2015 \quad$ Available at:http://www.wipo.int/edocs/pubdocs/en/wipo_pub_944_2015.pdf

World intellectual property organization (WIPO), who filed the most PCT patent applications in 2016 ? Available at:http://www.wipo.int/export/sites/www/ipstats/en/docs/infographic_pct_2016.pdf

World intellectual property organization (WIPO), International Patent Filings Set New Record in 2011 $\begin{array}{lllll}\text { Geneva, } & \text { March } & \text { 5, } & \text { Available }\end{array}$ at:http://www.wipo.int/pressroom/en/articles/2012/article_0001.html

World intellectual property organization (WIPO), US and China Drive International Patent Filing Growth in Record-Setting Year (Geneva, March 13,2014) Available at:http://www.wipo.int/pressroom/en/articles/2014/article_0002.html

World intellectual property organization (WIPO), Advisory Committee on Enforcement (Eleventh Session)

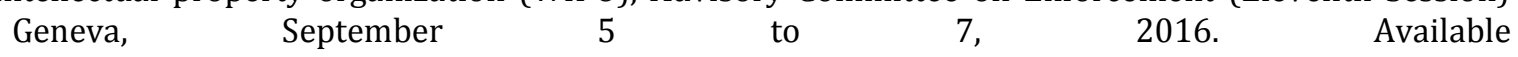
at:http://www.wipo.int/edocs/mdocs/enforcement/en/wipo_ace_11/wipo_ace_11_6.pdf

World intellectual property organization (WIPO), China: IP Laws and Treaties Available at:http://www.wipo.int/wipolex/en/profile.jsp?code=cn. 